\title{
Changing health care culture: a prerequisite to improving patient safety
}

This article was published in the following Dove Press journal:

Therapeutics and Clinical Risk Management

8 May 2017

Number of times this article has been viewed

\section{Saeed Azizi \\ Faisal Siddiqui \\ Ithsham Iqbal}

Faculty of Medicine, St George's Hospital Medical School, London, UK
Correspondence: Saeed Azizi Faculty of Medicine, St George's Hospital Medical School, Cranmer Terrace, London SWI 7 ORE, UK

Tel +44 798520 I878

Email saeedazizi.sa@gmail.com

\section{Dear editor}

We read the recent article by Chua et $\mathrm{al}^{1}$ with great interest. We found it thought-provoking to read how novel interventions, such as sharing errors, among the team can reduce the frequency of error recurrence in the future. We are hopeful that if such interventions were applied to other areas of health care, it would yield similar results. Having said this, we strongly believe that an important prerequisite of openness among health care workers is required for such interventions to work.

To facilitate a culture of openness among health care workers, it is important to understand the role hierarchy plays in the health care environment. Walton ${ }^{2}$ describes medical hierarchy as a relationship founded on the "difference of power between a superior and subordinate rather than the relationship between teacher and learner". Although medical hierarchy has been shown to be effective in certain areas, such as accountability, it does also provide space for the possibility of negative behavior, such as bullying. Such behavior impacts not only those directly affected, but ultimately is detrimental to patient safety and the quality of care provided.

In the UK, there have been growing concerns regarding workplace bullying and the impact it has on staff and patient safety. The General Medical Council (GMC) sends out the national training survey (NTS) annually to doctors in training, requesting feedback of their experiences. The recent 2016 GMC NTS $^{3}$ found that 1 in 20 doctors in training had a bullying or undermining concern; however, $29 \%$ of these doctors did not report these concerns out of fear of adverse consequences. This fear of adverse consequences also extends to many health care professionals who are reluctant to raise patient safety concerns. ${ }^{4}$ For interventions stated in the original research to be functional, it is paramount that health care professionals feel safe and comfortable to highlight errors openly.

To facilitate a more open culture in health care, it is important to understand the role played by those in senior positions. West et $\mathrm{al}^{5}$ state that leadership is the most influential factor in impacting organizational culture. Good leadership that does not foster a culture of blame is paramount in creating a health care environment where other members of the team can speak up comfortably and share errors so that others can learn.

To create an environment of openness, we recommend flattening the hierarchy by establishing a culture within the medical team that respects all members of the team, irrespective of their designation, and treats all members with an equal amount of respect and consideration. This is not the same as abolishing the hierarchy, as a clinical 
hierarchy needs to remain to ensure optimal patient care. However, from a cultural perspective, the hierarchy should be as flat as possible to empower health care professionals to raise concerns and share errors with the team.

\section{Disclosure}

The authors report no conflicts of interest in this communication.

\section{References}

1. Chua SS, Choo SM, Sulaiman CZ, Omar A, Thong MK. Effects of sharing information on drug administration errors in pediatric wards : a prepost intervention study. Ther Clin Risk Manag. 2017;13:345-353.
2. Walton MM. Hierarchies: the Berlin Wall of patient safety. Qual Saf Health Care. 2006;15(4):229-230.

3. General Medical Council. National Training Survey 2016.

4. Okuyama A, Wagner C, Bijnen B. Speaking up for patient safety by hospital-based health care professionals: a literature review. BMC Health Serv Res. 2014;14:61.

5. West M, Armit K, Loewenthal L, Eckert R, West T, Lee A. Leadership and leadership development in health care: the evidence base. Kings Fund. 2015:1-36.

Dove Medical Press encourages responsible, free and frank academic debate. The content of the Therapeutics and Clinical Risk Management 'letters to the editor' section does not necessarily represent the views of Dove Medical Press, its officers, agents, employees, related entities or the Therapeutics and Clinical Risk Management editors. While all reasonable steps have been taken to confirm the content of each letter, Dove Medical Press accepts no liability in respect of the content of any letter, nor is it responsible for the content and accuracy of any letter to the editor.

\section{Publish your work in this journal}

Therapeutics and Clinical Risk Management is an international, peerreviewed journal of clinical therapeutics and risk management, focusing on concise rapid reporting of clinical studies in all therapeutic areas, outcomes, safety, and programs for the effective, safe, and sustained use of medicines. This journal is indexed on PubMed Central, CAS,
EMBase, Scopus and the Elsevier Bibliographic databases. The manuscript management system is completely online and includes a very quick and fair peer-review system, which is all easy to use. Visit http://www.dovepress.com/testimonials.php to read real quotes from published authors.

Submit your manuscript here: http://www.dovepress.com/therapeutics-and-clinical-risk-management-journal 